\title{
Comparison of nekton use of Phragmites australis and Spartina alterniflora marshes in the Chesapeake Bay, USA
}

\author{
David L. Meyer ${ }^{1, *}$, John M. Johnson ${ }^{1}$, John W. Gill ${ }^{2}$ \\ ${ }^{1}$ NOAA, Center for Coastal Fisheries and Habitat Research, 101 Pivers Island Road, Beaufort, North Carolina 28516, USA \\ ${ }^{2}$ USFWS ,177 Admiral Cochran Drive, Annapolis, Maryland 21401, USA
}

\begin{abstract}
Throughout the eastern USA many Spartina alterniflora salt-marsh systems are being altered through the invasion of Phragmites australis. As a result, substantial declines in the areal distribution of $S$. alterniflora-dominated habitat have occurred in contrast to increases in $P$. australis dominated habitat. While information is scarce on nekton use of $P$. australis marsh, increases in the areal distribution of this species have concerned resource managers. Managers typically view the shift of $S$. alterniflora to $P$. australis marsh as a shift from a biologically diverse and productive marsh to one less biologically diverse and productive. We examined nekton use of $P$. australis marsh relative to $S$. alterniflora marsh with similar geographic location and physical conditions. We found no significant differences $(\mathrm{p}>0.05)$ in the utilization of $P$. australis and $S$. alterniflora marsh by nekton in terms of abundance or biomass. Further, no significant difference $(p>0.05)$ in the total number of nekton species was evident between $P$. australis and S. alterniflora marsh. We postulate that under similar environmental and physical conditions these marsh types are equivalent in terms of nekton use. It may be necessary to reevaluate current wetland management practices which involve the elimination of $P$. australis in favor of $S$. alterniflora marsh in order to increase nekton use.
\end{abstract}

KEY WORDS: Phragmites · Spartina · Nekton · Fish · Shrimp · Fauna · Alteration · Invasion · Disruption $\cdot$ Utilization $\cdot$ Restoration $\cdot$ Marsh $\cdot$ Fundulus $\cdot$ Palaemonetes

Resale or republication not permitted without written consent of the publisher

\section{INTRODUCTION}

The loss of salt-marsh habitat is a concern to North American fishery managers because many coastal nekton species in North America rely on this habitat during some life-history stage. Although salt-marsh loss by natural processes such as erosion (Wray et al. 1995, Meyer et al. 1997) and sea-level change (Webb et al. 1995) is inevitable, additional loss or alteration due to direct and indirect human impact occurs (Sinicrope et al. 1990, Havens et al. 1997). While the physical alteration of marsh habitat is considered an immediate threat, the progressive change through indirect influences on the estuarine environment (such as

\footnotetext{
*E-mail: dave.meyer@noaa.gov
}

water quality, water circulation impediments, freshwater runoff, etc.) can also be substantial and might shift ecosystem equilibrium. Once equilibrium shifts occur, changes in dominant floral and faunal species could follow.

Habitat alteration is occurring on a global scale, and shifts in macrophyte dominance have been observed throughout the world including those in Asia (Dudgeon 1992), Europe (Rico \& Fernandez 1997) and North America (Keast 1984, Rice 1996). Throughout the eastern USA, the dominant floral composition of many salt-marsh systems is threatened by alteration. Invasive species including reed grass (Phragmites australis) may invade wetlands, spread, and reduce openwater habitat (Caffrey 1996, Broyer \& Varagnat 1998), and/or replace dominant macrophyte species through natural habitat (Sinicrope et al. 1990, Havens et al. 
1997) or anthropogenically derived (Rice 1996, Havens et al. 1997) disturbances. Substantial declines in Spartina alterniflora areal coverage have occurred in the USA due to encroachment into mesohaline estuarine areas by $P$. australis (Rice 1996, Havens et al. 1997), a species typically thought to be native to oligohaline wetlands, including those of North America (Niering \& Warren 1977, Orson et al. 1987). While the total amount of salt marsh might remain constant, there are general concerns by North American resource managers that the shift from $S$. alterniflora-dominated to $P$. australis-dominated marsh could result in a change from a biodiverse, fisheries-productive $S$. alterniflora marsh (Bozeman \& Dean 1980, Boesch \& Turner 1984, Zimmerman \& Minello 1984, Hettler 1989, Minello \& Zimmerman 1992, Minello et al. 1994) to a less biodiverse, unproductive $P$. australis marsh. While $P$. australis marsh may produce substantial vegetation biomass, North American P. australis marshes have been noted to be utilized by fewer avian species than Spartina spp. marshes (Benoit \& Askins 1999), and are theorized to have little fisheries value (Hellings \& Gallagher 1992, Kay 1995, Roman et al. 1997).

Differences in wetland management practices within North America and other continents do occur, because while globally Phragmites australis is considered a species which needs to be managed and controlled, outside of North America P. australis has also been considered an important habitat for fauna. Substantial information on the eradication of $P$. australis from North American marshes (van der Toorn \& Mook 1982, Thompson \& Shay 1985, 1989, Kay 1995) is available due to resource allocation for the elimination of $P$. australis in favor of Spartina alterniflora or some other more desirable marsh-grass species. While in other parts of the world there is affirmation of the importance of maintaining the integrity of other habitat types through the control of $P$. australis (Caffrey 1996, Broyer \& Varagnat 1998), there is also concern for the loss (Newell 1978, Tscharntke 1992) and fragmentation of the endangered, rare, expansive monotypic $P$. australis wetlands, which are now often found only in reserves (Tscharntke 1992), as well as concern for the subsequent decline of biota associated with disruption of this habitat (Tscharntke 1992, Ostendorp 1993). Because of the broader view on the function of $P$. australis marshes in other parts of the world, information is available which not only targets control and maintenance of $P$. australis marshes (Cowie et al. 1992) but its potential importance to biota. $P$. australis has been noted to be an important vector for trophic energy exchange and a carbon source for fishes in Africa (Whitfield 1980, Doergeloh 1985), important in terms of avian (Tscharntke 1992, Ostendorp 1993, Balint et al. 1998, Broyer \& Varagnat 1998) and macroinvertebrate use in Europe
(Ostendorp 1993, Armitage et al. 1995, Arnold \& Ormerod 1997), and fish use in Europe (Ostendorp 1993, Balint et al. 1998), Africa (Whitfield 1980, Blaber 1982) and Asia (Yu et al. 1994).

While it has been noted that the full importance of the Phragmites australis habitat for nekton is still not well known in Europe (Ostendorp 1993), information on the function of North American P. australis marsh is substantially lacking, but now coming to light. Numerous investigations are currently being undertaken to evaluate the function of the North American P. australis marsh. Work by Fell et al. (1998) has noted similarities in abundance and mummichog diet (Fundulus heteroclitus) from marsh creeks bisecting $P$. australis, and $P$. australis-free high marsh in Connecticut, USA. Similarly, the identification of $P$. australis isotope signatures in marsh nekton within Delaware Bay, USA, suggests that this macrophyte may be an important component of the estuarine food web (Wainright et al. 2000). It is evident that the information void on nekton use of North American P. australis-dominated marsh is now beginning to be filled with data indicating a potential importance of $P$. australis marsh in terms of fisheries habitat value.

In order to determine the potential affects that an invasive macrophyte species such as Phragmites australis may have on salt-marsh functions, we initiated this study. The objectives of the study were to: (1) increase our limited knowledge of the function of North American P. australis marshes in terms of nekton use, and (2) to compare nekton abundance, biomass and diversity for $P$. australis and Spartina alterniflora marshes with similar geographic locations and similar physical conditions.

\section{METHODS}

Study sites. The study sites were located within the Chester River and Prospect Bay regions of Chesapeake Bay, Maryland, USA, along a meso-oligohaline interface. Two low-marsh stations of the same stream order (Rozas \& Odum 1987, Hettler 1989), 1 of Phragmites australis and 1 of Spartina alterniflora were selected within each of the 5 study sites (Fig. 1). The paired marsh stations within a study site were a minimum of $100 \mathrm{~m}$ (Marshy Creek South) and a maximum of 400 m (Piney Creek, Muddy Creek, Marshy Creek North and Marshy Creek East) apart. All marsh stations were typically gently sloping and contained numerous vegetated hummocks interspersed by small ( 20 to $30 \mathrm{~cm}$ wide) sinuous channels. Paired marsh stations were located on the same creek, with separate pairs being at least $1 \mathrm{~km}$ apart, and located on separate creeks or tributaries. All study sites and marsh stations 


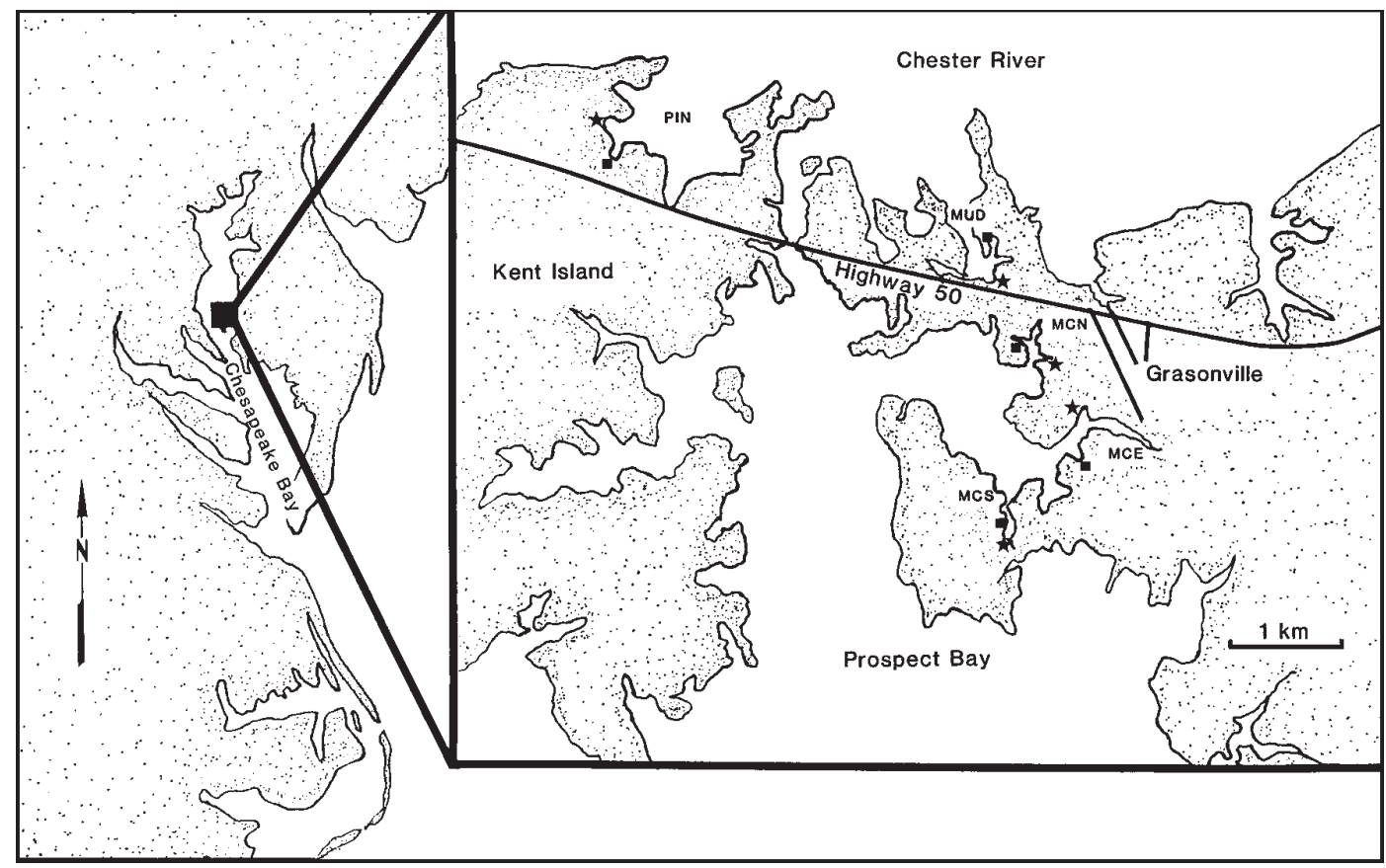

Fig. 1. Study-site locations in Chesapeake Bay, Maryland. Each of the 5 sites is designated by a 3-letter designation. PIN = Piney Creek; MUD = Muddy Creek; MCN = Marshy Creek North; MCE = Marshy Creek East $;$ MCS = Marshy Creek South. Locations of Phragmites australis ( $\star$ ) and Spartina alterniflora ( $\mathbf{\square})$ sample areas within each site

were selected during initial site surveys, based on the occurrence of the dominant vegetation and apparent similarities in salinity, elevation, topographical slopes and hydroperiod.

Vegetation. Marsh stations at each study site were characterized for vegetation dominance through stemdensity counts and morphometrics, based on methodology used by Cowie et al. (1992), during each collection period (May, July and October 1997). To account for vegetation zonation within each of the $6 \mathrm{~m}$ deep $\times$ $10 \mathrm{~m}$ wide nekton collection areas, which encompassed each marsh station, each marsh station was divided into two $3 \mathrm{~m}$ deep $\times 10 \mathrm{~m}$ wide sections: the lower marsh section, which encompassed an area from the lower marsh fringe up to $3 \mathrm{~m}$ into the marsh, and the upper marsh section which encompassed the area from 3 to $6 \mathrm{~m}$ from the lower fringe. Within each $6 \mathrm{~m} \times$ $10 \mathrm{~m}$ nekton collection area at a marsh station, 4 randomly selected vegetation count locations were located: 2 count locations within the lower marsh section and 2 within the upper section. Within each count location, the number of live and dead plant stems within a $0.25 \mathrm{~m}^{2}$ quadrat were recorded for each plant species.

Percent areal stem coverage was estimated for each stem-count quadrat by measuring the diameter for up to 10 live and 10 dead stems (at $10 \mathrm{~cm}$ ) of each macrophyte species encountered within the quadrat with a vernier caliper to the nearest $0.1 \mathrm{~mm}$. Stems were chosen based on closest proximity to a pre-determined quadrate corner. Areal stem coverage was then estimated for each quadrate by multiplying the mean stem diameter for each macrophyte species by the number of stems observed for that species.

Environment. Salinity, water temperature, elevation at the marsh fringe and $6 \mathrm{~m}$ landward of the marsh fringe and marsh slope were measured for each macrophyte marsh station at each study site during each collection period, and the frontal marsh slope was measured during the fall. Both salinity (measured with a temperature-compensated refractometer, accuracy of $0.1 \%$ ), and temperature were measured once the fyke and block nets used to collect nekton had been set. Relative marsh elevations for each macrophyte marsh station were measured during high tide to the nearest $1 \mathrm{~cm}$ following a method employed by Meyer (1994), using the water surface as a level. Once nets had been set, the water depth was measured at 3 points along both sides of the $10 \mathrm{~m}$ wide collection plots; at the mouth of the fyke net, at the fyke net stakes on the front fringe of the marsh, and at the block net stakes located $6 \mathrm{~m}$ back into the marsh. The 2 sets of measurements collected for each macrophyte marsh station were averaged to estimate marsh fringe elevation, frontal marsh slope (slope along the $3 \mathrm{~m}$ distance between the mouth of the fyke net and the marsh 
fringe) and the marsh slope (between the fringe to $6 \mathrm{~m}$ into the marsh) for the marsh station at each study site. Distance of water incursion from the marsh fringe into each macrophyte marsh station was also measured, to the nearest $0.1 \mathrm{~m}$, during each collection period.

Marsh fauna. During May, July and October 1997, nekton collections were made at each marsh station within each study site using methods similar to those of Hettler (1989). These collection dates were used in order to examine marsh usage by nekton during different critical life-history stages. Fyke nets with a mouth measuring $1 \mathrm{~m}^{2}$ with $3.4 \mathrm{~m}$ wings in combination with $6 \mathrm{~m}$ block nets were used. Nets were constructed of black $3.2 \mathrm{~mm}$ stretch-mesh netting. At each site, 10 contiguous linear meters of marsh fringe were demarcated and sampled using paired fyke nets. On the day prior to nekton collections, paired sets of fyke-net attachment poles were set along the marsh fringe so that when fyke nets were set and attached to the poles 10 contiguous meters of marsh edge would be fished. One $6 \mathrm{~m}$ long block net was attached to each of the outer fyke-net attachment poles. In addition to fykenet attachment poles, block-net attachment poles were set $6 \mathrm{~m}$ into the marsh from the fringe and $10 \mathrm{~m}$ apart. Block nets were folded and bundled to each outer fyke-net attachment pole in preparation for marshfauna collection. During site preparation, debris which might hinder the net lead line set on the bottom was removed from the area along which the nets would be deployed. Preparation included the connection of each block-net top to guidelines which were strung between the fyke net and back block-net poles. To reduce disturbance when sampling, a pull line was connected to the free end of each block net. When this line was pulled, the block net would slide along a guideline to the back pole and block off the lateral movement of nekton within the $10 \times 6 \mathrm{~m}$ nekton collection area of the marsh station. While there is a recognized potential for nekton movement in and out of the back of the cordoned-off $6 \mathrm{~m}$ deep nekton collection area, such movement was considered to have a minimal effect on marsh-use comparisons because of the potential of nekton-movement similarities for the Phragmites australis and Spartina alterniflora marshes sampled. Further, notations in other studies suggest that the majority of nekton collected within marshes utilize the area within $3 \mathrm{~m}$ (Peterson \& Turner 1994) to $5 \mathrm{~m}$ (Minello et al. 1994) of the marsh fringe, and that up to $98 \%$ of total nekton abundance is concentrated within $2 \mathrm{~m}$ of the marsh fringe (Baltz et al. 1993). Once a site was prepared, it was allowed to settle for at least 1 complete tidal cycle prior to sampling. Fyke and block nets were deployed at a site during a morning high tide for same-day sampling of paired marsh stations within a study site. Nekton were collected once the tide had evacuated from the fyke nets during the subsequent low tide, and the collection areas were surveyed for nekton stranded on the marsh surface. Nekton were preserved in $95 \%$ ethanol, and later all fishes, shrimps and crabs were identified to species. For each marsh station, the number of individuals and wetweight biomass for each species were recorded. All individuals for a species were measured or, if numerically abundant, a randomly selected subsample of at least 100 individuals or $10 \%$ of the total (whichever was higher) was measured (standard length for fishes, total length for shrimps and carapace width for crabs).

Statistical analysis. A Student's $t$-test for paired data comparisons was used to test the mean differences between the marsh types in this study (Ott 1993) using the SAS Statistical Analysis System (SAS Institute Inc 1985). Each fyke/block-net pair within a marsh station (marsh type) at each of the sites was considered a replicate for nekton $(n=5)$ and was analyzed as such during each collection period. This included comparisons of lengths, biomass and abundances of individual species, and biomass and total abundances for groupings of fishes, shrimps and crabs. A replicate for vegetation parameters including, stem-density counts and estimates of areal stem coverages was considered to be the marsh area encompassed within the fyke-net collections for a marsh type at each site $(n=5)$ and analyzed as such. Physical parameters including salinities, temperatures, mean marsh elevations, and frontal marsh and marsh slopes (all sites included, $\mathrm{n}=5$ ) were compared between macrophyte marsh types.

\section{RESULTS}

\section{Vegetation}

Based on vegetation surveys, 8 macrophyte species were common within marshes sampled with a total of 7 species observed within each marsh type. Of the 8 species, 6 were observed in both Phragmites australis and Spartina alterniflora dominated marshes. Of the remaining 2 species, 1 (Iva frutescens) was only observed in the $P$. australis marshes, and the other (Distichlis spicata) was only observed in the $S$. alterniflora marshes. $P$. australis and $S$. alterniflora had a minor presence in opposing marsh types. Within the $P$. australis-dominated marshes, 1 species ( $P$. australis) was numerous, and the 6 other species comprising Solidago sempervirens, Aster tenuifolius, Scirpus americanus, I. frutescens and $S$. alterniflora were less numerous (Fig. 2). Within the $S$. alterniflora-dominated marshes, 3 species were numerous, $S$. alterniflora, D. spicata and Spartina patens, while the other 4 species, $S$. sem- 


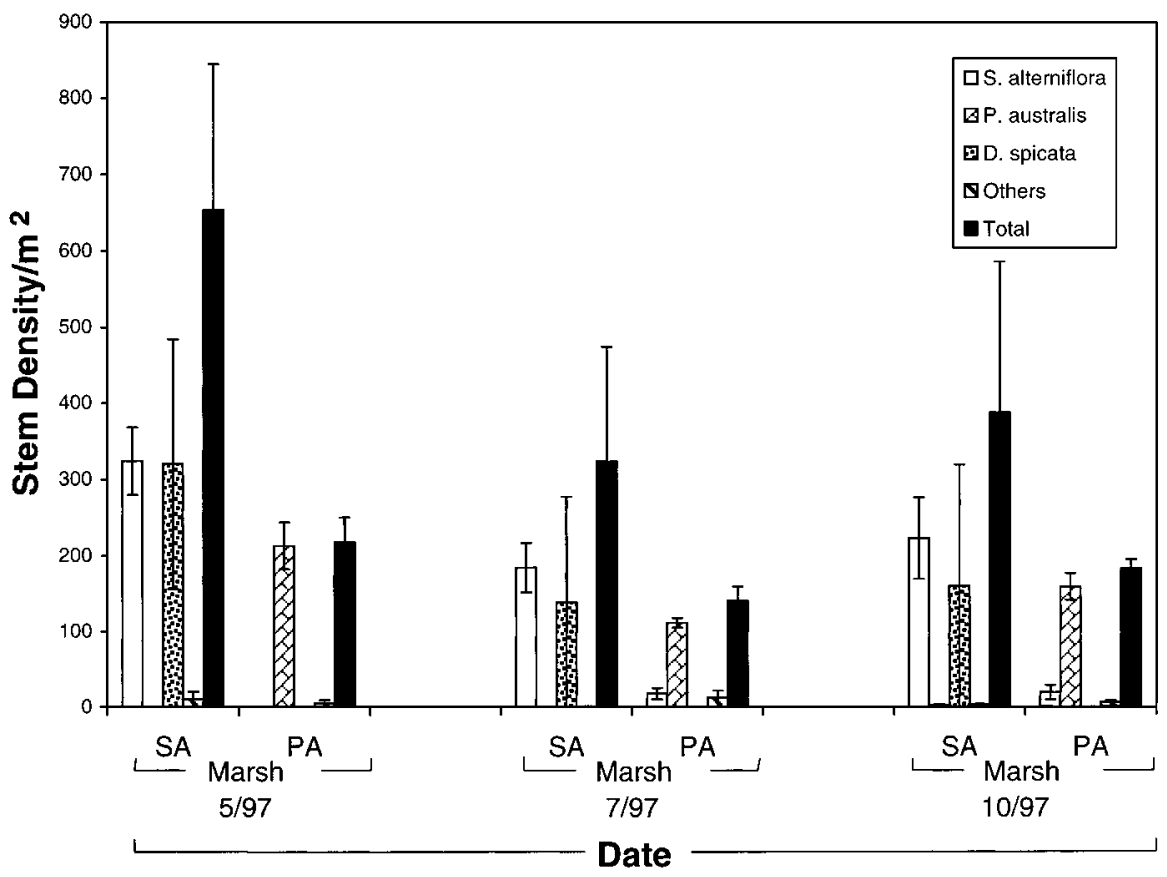

Fig. 2. Mean vegetation stem-density $\mathrm{m}^{-2}( \pm 1 \mathrm{SE})$ by date, for dominant species, and stem density for all species combined, within Spartina alterniflora (SA), and Phragmites australis (PA) marsh types. $\mathrm{n}=5$ for the means of both $S$. alterniflora and P. australis marsh types. D. spicata: Distichlis spicata

pervirens, S. americanus, A. tenuifolius and $P$. australis were less numerous (Fig. 2). During each collection period, significantly higher $P$. australis stem densities were observed within the $P$. australis compared to the $S$. alterniflora marshes (spring $\mathrm{p}=0.0001$, summer $\mathrm{p}=$ 0.0001 , fall $p=0.0009$ ), and significantly higher stem densities of $S$. alterniflora were observed within the $S$. alterniflora compared to the $P$. australis marshes (spring $\mathrm{p}=0.0001$, summer $\mathrm{p}=0.006$ and fall $\mathrm{p}=0.002$ ) (Fig. 2). Total stem density, all species combined, tended to be consistently higher in the $S$. alterniflora than in the $P$. australis marshes; however, no significant differences were detected between marsh types (spring $\mathrm{p}=0.08$, summer $\mathrm{p}=0.30$, fall $\mathrm{p}=0.36$ ).

Areal stem coverage varied little between Phragmites australis- and Spartina alterniflora-dominated marshes. A high of $\sim 3.3$ to $3.6 \%$ of the marsh area was taken up by stems during spring, and $\sim 0.7$ to $1.2 \%$ during the summer and fall periods (Table 1). No significant difference $(p>0.05)$ was observed between marsh types in regard to areal stem coverage during any collection period (Table 1).

\section{Environment}

Salinities and temperatures measured during faunal collections did not significantly differ $(p>0.05)$ between Phragmites australis and Spartina alterniflora marshes during spring, summer or fall collections (Table 1). Topographical marsh features were also similar between the macrophyte marsh types. Marshfringe elevation (as measured from mean high water) did not differ significantly between the $P$. australis and $S$. alterniflora marshes during any of the collection periods nor did elevations observed at a distance of $6 \mathrm{~m}$ into the marsh (Table 1). Similarly, no significant differences between $P$. australis and $S$. alterniflora marsh types were evident in terms of marsh slopes during spring, summer or fall collections $(p=0.27, p=0.08, p=$ 0.08 , respectively) nor for the frontal marsh slope during fall ( $p>0.05)$, (Table 1$)$. No significant differences in terms of distance of water incursion into the $P$. australis and $S$. alterniflora marsh types were evident during spring, summer or fall collections (Table 1).

\section{Marsh fauna}

A total of 21 fish, 1 shrimp and 3 crab species were collected over the course of this study (Tables $2 \& 3$ ). The crab species collected made a relatively small contribution to overall faunal abundance and biomass. Two crab species collected, Rithropanopeus harrisii and Callinecties sapidus, were common to both Phragmites australis and Spartina alterniflora marshes, while the third, Dyspanopeus sayi was observed only within the $S$. alterniflora marshes. The grass shrimp Palae- 
Table 1. Phragmites australis and Spartina alterniflora. Mean physical parameters measured for the marsh types in 1997. No significant differences $(\mathrm{p}>0.05)$ were observed between marsh types for any of the parameters measured. -: no observations taken during sampling period

\begin{tabular}{|c|c|c|c|c|c|c|c|c|}
\hline Marsh type & $\begin{array}{l}\text { Marsh fringe } \\
\text { elevation }(\mathrm{cm})\end{array}$ & $\begin{array}{l}\text { Marsh elevation } \\
\text { at } 6 \mathrm{~m}(\mathrm{~cm})\end{array}$ & $\begin{array}{l}\text { Distance of water } \\
\text { incursion(m) }\end{array}$ & $\begin{array}{c}\text { Frontal marsh } \\
\text { slope }\end{array}$ & Marsh slope & $\begin{array}{l}\text { Salinity } \\
\text { (\%o) }\end{array}$ & $\begin{array}{l}\text { Temp. } \\
\left({ }^{\circ} \mathrm{C}\right)\end{array}$ & $\begin{array}{c}\% \text { areal } \\
\text { stem coverage }\end{array}$ \\
\hline \multicolumn{9}{|l|}{ May } \\
\hline P. australis & -26.8 & -11.9 & 22.1 & - & 0.027 & 5.4 & 13.1 & 3.3 \\
\hline S. alterniflora & -28.0 & -18.6 & 36.8 & - & 0.017 & 5.2 & 13.2 & 3.6 \\
\hline \multicolumn{9}{|l|}{ July } \\
\hline P. australis & -45.4 & -20.2 & 33.1 & - & 0.046 & 8.0 & 26.7 & 0.7 \\
\hline S. alterniflora & -42.8 & -30.7 & 45.8 & - & 0.022 & 8.2 & 26.7 & 1.2 \\
\hline \multicolumn{9}{|l|}{ October } \\
\hline P. australis & -34.5 & -15.2 & 37.5 & 0.051 & 0.035 & 10.0 & 13.2 & 1.0 \\
\hline S. alterniflora & -31.6 & -21.2 & 41.7 & 0.052 & 0.019 & 10.0 & 13.1 & 1.2 \\
\hline \multicolumn{9}{|c|}{ Average for year } \\
\hline P. australis & -35.6 & -15.8 & 30.9 & 0.051 & 0.036 & 7.8 & 17.7 & 1.7 \\
\hline S. alterniflora & -34.1 & -23.5 & 41.4 & 0.052 & 0.019 & 7.8 & 17.7 & 2.0 \\
\hline
\end{tabular}

monetes pugio was common to both marsh types, and accounted for a substantial amount of the overall catch during fall. A total of 15 fish species were common to both marsh types overall, with 5 species collected only in $P$. australis and 1 species collected only in $S$. alterniflora (Tables $2 \& 3$ ). While more species were collected within the $P$. australis marsh during spring (15), and summer (19) than within the $S$. alterniflora marsh (10 spring, 17 summer) no significant differences ( $p>0.05$ ) based on mean number of species present were detected (Tables 2 \& 3). During the fall, the total number of species collected was 16 for both the $P$. australis and $S$. alterniflora, and the total number of species collected for the year overall was higher in the $P$. australis marsh (23), than in the $S$. alterniflora marsh (20); however, again no significant difference based on mean number of species present was detected $(\mathrm{p}>$ 0.05).

Ranking nekton species based on the percent of the catch which they comprised in abundance and biomass during each collection period revealed substantial similarities in the composition of the species complement for Phragmites australis- and Spartina alterniflora-dominated marshes. In general, 3 to 6 of the species present within $P$. australis and $S$. alterniflora marshes during each collection period composed $95 \%$ of the nekton abundance and biomass (Table 2). Species which were consistently among the more dominant in terms of abundance and biomass included Fundulus heteroclitus, Cyprinodon variegatus, Palaemonetes pugio and Fundulus diaphanus. Seasonal dominance was evident for other species including Menidia beryllina, Fundulus luciae, Morone americanus, Lepomis gibbosus, Anguilla rostrata and Callinecties sapidus during the summer and Lucania parva and Fundulus majalis during the fall (Table 2). Among the more evident differences in use patterns between $P$. australis- and $S$. alterniflora-dominated marshes were the consistently higher percentages of catch that $C$. variegatus made up within $S$. alterniflora compared to $P$. australis marshes throughout the year and the higher proportion of catch that $P$. pugio made up within $P$. australis during the spring and fall compared to $S$. alterniflora marshes (Table 2).

The abundances of total nekton (all species combined) and total fishes (all fish species combined), did not significantly differ $(\mathrm{p}>0.05)$ between the Phragmites australis and Spartina alterniflora marshes during any collection period (Fig. 3). Significantly different abundances were evident for only 2 species: Cyprinodon variegatus, which was present in higher abundance in $S$. alterniflora than in $P$. australis marshes during summer and fall $(\mathrm{p}=0.02, \mathrm{p}=0.03$, respectively); and Lepomis gibbosus, which was present in higher abundance in $P$. australis than in S. alterniflora marshes during fall ( $\mathrm{p}=0.05$ ) (Table 3$)$.

No significant differences $(p>0.05)$ in the abundances of the 1 shrimp species collected (Palaemonetes pugio), were detected between Phragmites australis and Spartina alterniflora marshes for any collection period (Table 3, Fig. 3). No significant differences between $P$. australis and $S$. alterniflora marshes were observed for the abundances of the 3 crab species collected (Rithropanopeus harrisii, Callinecties sapidus and Dyspanopeus sayi), nor for total crab abundances (all crab species combined) for any collection date (Table 3, Fig. 3).

Total wet-weight biomass for all species combined, all fish species combined, shrimp, and all crab species combined did not significantly differ between the Phragmites australis and Spartina alterniflora marshes for any collection date (Fig. 4). Significant differences 
Table 2. Rank of fish and decapod species observed in fyke- and block-net collections in Phragmites australis and Spartina alterniflora marshes based on percent abundance and biomas

\begin{tabular}{|c|c|c|c|c|c|c|c|c|c|c|c|}
\hline \multicolumn{6}{|c|}{ Abundance } & \multicolumn{6}{|c|}{ Biomass } \\
\hline & \multirow{2}{*}{$\begin{array}{l}\text {-Phragmites australis - } \\
\text { Species }\end{array}$} & & \multicolumn{3}{|c|}{ Spartina alterniflora } & \multirow{2}{*}{$\overline{\text { Rank }}$} & \multirow{2}{*}{$\begin{array}{l}\text {-Phragmites australis - } \\
\text { Species }\end{array}$} & \multirow{2}{*}{$\overline{\%}$} & \multirow{2}{*}{$\overline{\text { Rank }}$} & \multirow{2}{*}{$\begin{array}{l}\text { Spartina alterniflora } \\
\text { Species }\end{array}$} & \multirow[b]{2}{*}{$\%$} \\
\hline Rank & & $\%$ & Rank & Species & $\%$ & & & & & & \\
\hline \multicolumn{12}{|c|}{ May 1997} \\
\hline 1 & Fundulus heteroclitus & 54.3 & 1 & Fundulus heteroclitus & 63.3 & 1 & Fundulus heteroclitus & 84.1 & 1 & Fundulus heteroclitus & 78.8 \\
\hline 2 & Palaemonetes pugio & 34.8 & 2 & Palaemonetes pugio & 21.0 & 2 & Fundulus diaphanus & 9.3 & 2 & Fundulus diaphanus & 15.3 \\
\hline 3 & Fundulus diaphanus & 7.4 & 3 & Fundulus diaphanus & 11.7 & 3 & Palaemonetes pugio & 3.6 & 3 & Cyprinodon variegatus & 2.7 \\
\hline 4 & Cyprinodon variegatus & 0.9 & 4 & Cyprinodon variegatus & 3.0 & 4 & Lepomis gibbosus & 1.4 & 4 & Palaemonetes pugio & 2.4 \\
\hline 5 & Lucania parva & 0.8 & 5 & Lucania parva & 0.7 & 5 & Cyprinodon variegatus & 0.7 & 5 & Lepomis gibbosus & 0.3 \\
\hline 6 & Apeltes quadracus & 0.7 & 6 & Lepomis gibbosus & 0.1 & 6 & Anguilla rostrata & 0.3 & 6 & Menidia beryllina & 0.1 \\
\hline 7 & Lepomis gibbosus & 0.6 & 6 & Rithropanopeus harrisii & 0.1 & 7 & Lucania parva & 0.2 & 6 & Lucania parva & 0.1 \\
\hline 8 & Rithropanopeus harrisii & 0.1 & 7 & Fundulus majalis & $<0.1$ & 8 & Perca flavescens & 0.1 & 7 & Rithropanopeus harrisii & $<0.1$ \\
\hline 9 & Menidia beryllina & $<0.1$ & 7 & Fundulus luciae & $<0.1$ & 8 & Apeltes quadracus & 0.1 & 7 & Fundulus majalis & $<0.1$ \\
\hline 9 & Anguilla rostrata & $<0.1$ & 7 & Menidia beryllina & $<0.1$ & 9 & Rithropanopeus harrisii & $<0.1$ & 7 & Fundulus luciae & $<0.1$ \\
\hline 9 & Brevoortia tyrannus & $<0.1$ & & & & 9 & Menidia beryllina & $<0.1$ & & & \\
\hline 9 & Fundulus luciae & $<0.1$ & & & & 9 & Menidia menidia & $<0.1$ & & & \\
\hline 9 & Lepomis macrochirus & $<0.1$ & & & & 9 & Lepomis macrochirus & $<0.1$ & & & \\
\hline 9 & Menidia menidia & $<0.1$ & & & & 9 & Brevoortia tyrannus & $<0.1$ & & & \\
\hline 9 & Perca flavescens & $<0.1$ & & & & 9 & Fundulus luciae & $<0.1$ & & & \\
\hline \multicolumn{12}{|c|}{ July 1997} \\
\hline 1 & Fundulus heteroclitus & 84.5 & 1 & Fundulus heteroclitus & 75.5 & 1 & Fundulus heteroclitus & 66.1 & 1 & Fundulus heteroclitus & 61.2 \\
\hline 2 & Cyprinodon variegatus & 5.0 & 2 & Cyprinodon variegatus & 14.4 & 2 & Morone americanus & 16.0 & 2 & Morone americanus & 21.6 \\
\hline 3 & Fundulus luciae & 3.1 & 3 & Menidia beryllina & 5.1 & 3 & Lepomis gibbosus & 6.3 & 3 & Lepomis gibbosus & 8.3 \\
\hline 4 & Menidia beryllina & 3.0 & 4 & Menidia menidia & 1.2 & 4 & Anguilla rostrata & 6.2 & 4 & Cyprinodon variegatus & 3.2 \\
\hline 5 & Morone americanus & 1.1 & 5 & Morone americanus & 1.0 & 5 & Callinecties sapidus & 1.4 & 5 & Menidia beryllina & 1.4 \\
\hline 6 & Fundulus majalis & 0.8 & 6 & Lepomis gibbosus & 0.7 & 6 & Fundulus luciae & 1.0 & 6 & Perca flavescens & 1.0 \\
\hline 6 & Palaemonetes pugio & 0.8 & 7 & Gambusia affinis & 0.5 & 7 & Cyprinodon variegatus & 0.9 & 7 & Menidia menidia & 0.8 \\
\hline 7 & Lepomis gibbosus & 0.5 & 8 & Fundulus luciae & 0.4 & 8 & Menidia beryllina & 0.6 & 8 & Alosa aestivalis & 0.7 \\
\hline 8 & Gambusia affinis & 0.4 & 9 & Alosa aestivalis & 0.3 & 9 & Perca flavescens & 0.5 & 9 & Fundulus majalis & 0.6 \\
\hline 9 & Anguilla rostrata & 0.2 & 9 & Lucania parva & 0.3 & 10 & Morone saxatilis & 0.2 & 10 & Anguilla rostrata & 0.5 \\
\hline 10 & Rithropanopeus harrisii & 0.1 & 9 & Palaemonetes pugio & 0.3 & 10 & Fundulus diaphanus & 0.2 & 11 & Fundulus diaphanus & 0.4 \\
\hline 10 & Lucania parva & 0.1 & 10 & Fundulus majalis & 0.2 & 10 & Fundulus majalis & 0.2 & 12 & Fundulus luciae & 0.2 \\
\hline 10 & Menidia menidia & 0.1 & 11 & Fundulus diaphanus & 0.1 & 11 & Leiostomus xanthurus & 0.1 & 13 & Gambusia affinis & 0.1 \\
\hline 10 & Fundulus diaphanus & 0.1 & 12 & Rithropanopeus harrisii & $<0.1$ & 12 & Menidia menidia & $<0.1$ & 14 & Rithropanopeus harrisii & $<0.1$ \\
\hline 11 & Callinecties sapidus & $<0.1$ & 12 & Anguilla rostrata & $<0.1$ & 12 & Palaemonetes pugio & $<0.1$ & 14 & Lucania parva & $<0.1$ \\
\hline 11 & Leiostomus xanthurus & $<0.1$ & 12 & Perca flavescens & $<0.1$ & 12 & Gambusia affinis & $<0.1$ & 14 & Palaemonetes pugio & $<0.1$ \\
\hline 11 & Morone saxatilis & $<0.1$ & & & & 12 & Rithropanopeus harrisii & $<0.1$ & & & \\
\hline 11 & Perca flavescens & $<0.1$ & & & & 12 & Lucania parva & $<0.1$ & & & \\
\hline 11 & Strongylura marina & $<0.1$ & & & & 12 & Strongylura marina & $<0.1$ & & & \\
\hline \multicolumn{12}{|c|}{ October 1997} \\
\hline 1 & Palaemonetes pugio & 80.9 & 1 & Palaemonetes pugio & 45.7 & 1 & Fundulus heteroclitus & 45.2 & 1 & Fundulus heteroclitus & 44.0 \\
\hline 2 & Fundulus heteroclitus & 10.8 & 2 & Fundulus heteroclitus & 21.0 & 2 & Palaemonetes pugio & 32.6 & 2 & Fundulus diaphanus & 19.6 \\
\hline 3 & Cyprinodon variegatus & 3.0 & 3 & Cyprinodon variegatus & 12.2 & 3 & Cyprinodon variegatus & 5.9 & 3 & Palaemonetes pugio & 11.7 \\
\hline 4 & Fundulus diaphanus & 2.4 & 4 & Fundulus diaphanus & 10.1 & 3 & Fundulus diaphanus & 5.9 & 4 & Cyprinodon variegatus & 10.8 \\
\hline 5 & Lucania parva & 1.7 & 5 & Menidia beryllina & 5.3 & 4 & Fundulus luciae & 3.7 & 5 & Fundulus majalis & 4.4 \\
\hline 6 & Menidia beryllina & 0.8 & 6 & Lucania parva & 4.5 & 5 & Morone americanus & 3.1 & 6 & Menidia beryllina & 4.2 \\
\hline 7 & Fundulus majalis & 0.2 & 7 & Fundulus majalis & 0.6 & 6 & Lepomis gibbosus & 1.5 & 7 & Lucania parva & 1.9 \\
\hline 8 & Rithropanopeus harrisii & 0.1 & 8 & Menidia menidia & 0.4 & 7 & Menidia beryllina & 1.0 & 8 & Morone americanus & 1.9 \\
\hline 9 & Lepomis gibbosus & $<0.1$ & 9 & Rithropanopeus harrisii & 0.1 & 7 & Lucania parva & 1.0 & 9 & Menidia menidia & 1.2 \\
\hline 9 & Morone americanus & $<0.1$ & 9 & Gambusia affinis & 0.1 & 8 & Rithropanopeus harrisii & 0.1 & 10 & Rithropanopeus harrisii & 0.1 \\
\hline 9 & Apeltes quadracus & $<0.1$ & 10 & Morone americanus & $<0.1$ & 9 & Menidia menidia & $<0.1$ & 11 & Lepomis gibbosus & 0.1 \\
\hline 9 & Fundulus luciae & $<0.1$ & 10 & Lepomis gibbosus & $<0.1$ & 9 & Gobiosoma bosci & $<0.1$ & 12 & Gambusia affinis & $<0.1$ \\
\hline 9 & Gambusia affinis & $<0.1$ & 10 & Fundulus luciae & $<0.1$ & 9 & Fundulus luciae & $<0.1$ & 13 & Gobiosoma bosci & $<0.1$ \\
\hline 9 & Gobiosoma bosci & $<0.1$ & 10 & Gobiosoma bosci & $<0.1$ & 9 & Lepomis macrochirus & $<0.1$ & 13 & Lepomis macrochirus & $<0.1$ \\
\hline 9 & Lepomis macrochirus & $<0.1$ & 10 & Lepomis macrochirus & $<0.1$ & 9 & Apeltes quadracus & $<0.1$ & 14 & Fundulus luciae & $<0.1$ \\
\hline 9 & Menidia menidia & $<0.1$ & 10 & Dyspanopeus sayi & $<0.1$ & 9 & Gambusia affinis & $<0.1$ & 14 & Dyspanopeus sayi & $<0.1$ \\
\hline
\end{tabular}

in wet-weight biomass (WWB) for individual species were only detected for Lepomis gibbosus during fall, with $P$. australis having significantly $(p=0.03)$ higher WWB $\mathrm{g}^{-1}$ linear $\mathrm{m}$ of marsh edge than $S$. alterniflora marshes (Table 3).

Among the more dominant fish species, including Fundulus heteroclitus, Cyprinodon variegatus, F. diaphanus, F. majalis and Lepomis gibbosus, a trend of larger individuals per species based on average WWB ind $^{-1}$ (AWWBI = mean of the replicate total wet weight/ number of individuals) (Fig. 5) and mean size, as measured by mean standard length (Fig. 6), was generally observed within Phragmites australis relative to Spartina alterniflora (although not significant in most cases) throughout the 3 collection periods. Differences were noted to be significant during the spring, with F. heteroclitus AWWBI higher $(\mathrm{p}<0.04)$ within $P$. australis than within $S$. alterniflora (Fig. 5). Exceptions to this 
Table 3. Fish and decapod species observed during fyke- and block-net collections in Phragmites australis and Spartina alterniflora marshes. No.: number of individuals per linear meter of marsh fringe $( \pm 1 \mathrm{SE}) ;$ Biomass: $g$ wet weight biomass per linear meter of marsh fringe $( \pm 1 \mathrm{SE}) .{ }^{*}$ Significant difference $(\mathrm{p} \leq 0.05)$ between means of the marsh types for that species; $-:$ relevant species was not observed in that marsh type during that collection period

\begin{tabular}{|c|c|c|c|c|c|c|c|c|}
\hline \multirow[t]{2}{*}{ Species } & \multicolumn{8}{|c|}{ May 1997} \\
\hline & \multicolumn{2}{|c|}{ No. } & & & \multicolumn{2}{|c|}{ No. } & lora & \\
\hline Alosa aestivalis & - & - & - & - & - & - & - & - \\
\hline Anguilla rostrata & $<0.1$ & - & 0.81 & $( \pm 0.81)$ & 0.0 & - & 0.00 & - \\
\hline Apeltes quadracus & 1.5 & $( \pm 1.5)$ & 0.41 & $( \pm 0.40)$ & 0.0 & - & 0.00 & - \\
\hline Brevoortia tyrannus & $<0.1$ & - & $<0.01$ & 0.0 & - & 0.00 & - & \\
\hline Cyprinodon variegatus & 2.0 & $( \pm 1.1)$ & 2.37 & $( \pm 1.47)$ & 7.1 & $( \pm 4.7)$ & 8.68 & $( \pm 6.49)$ \\
\hline Fundulus diaphanus & 15.8 & $( \pm 9.4)$ & 29.58 & $( \pm 18.83)$ & 27.6 & $( \pm 16.0)$ & 48.62 & $( \pm 28.77)$ \\
\hline Fundulus heteroclitus & 115.2 & $( \pm 34.4)$ & 267.00 & $( \pm 87.65)$ & 149.8 & $( \pm 73.1)$ & 249.90 & $( \pm 127.63)$ \\
\hline Fundulus luciae & $<0.1$ & - & $<0.01$ & - & $<0.1$ & - & $<0.01$ & - \\
\hline Fundulus majalis & 0.0 & - & 0.00 & - & 0.1 & $( \pm 0.1)$ & 0.10 & $( \pm 0.10)$ \\
\hline Gambusia affinis & - & - & - & - & - & - & - & - \\
\hline Gobiosoma bosci & - & - & - & - & - & - & - & - \\
\hline Leiostomus xanthurus & - & - & - & - & - & - & - & - \\
\hline Lepomis gibbosus & 1.3 & $( \pm 1.3)$ & 4.57 & $( \pm 4.56)$ & 0.3 & $( \pm 0.3)$ & 1.07 & $( \pm 0.95)$ \\
\hline Lepomis macrochirus & $<0.1$ & - & 0.01 & $( \pm 0.01)$ & 0.0 & - & 0.00 & - \\
\hline Lucania parva & 1.8 & $( \pm 1.0)$ & 0.53 & $( \pm 0.30)$ & 1.6 & $( \pm 0.6)$ & 0.39 & $( \pm 0.16)$ \\
\hline Menidia beryllina & 0.1 & $( \pm 0.1)$ & 0.12 & $( \pm 0.12)$ & $<0.1$ & - & 0.44 & $( \pm 0.44)$ \\
\hline Menidia menidia & $<0.1$ & - & 0.07 & $( \pm 0.07)$ & 0.0 & - & 0.00 & - \\
\hline Morone americanus & - & - & - & - & - & - & - & - \\
\hline Morone saxatilis & - & - & - & - & - & - & - & - \\
\hline Perca flavescens & $<0.1$ & - & 0.42 & $( \pm 0.42)$ & 0.0 & - & 0.00 & - \\
\hline Strongylura marina & - & - & - & - & - & - & - & - \\
\hline \multicolumn{9}{|l|}{ Decapods } \\
\hline Callinecties sapidus & - & - & - & - & - & - & - & - \\
\hline Dyspanopeus sayi & - & - & - & - & - & - & - & - \\
\hline Palaemonetes pugio & 73.9 & $( \pm 25.8)$ & 11.58 & $( \pm 4.37)$ & 49.7 & $( \pm 15.7)$ & 7.59 & $( \pm 2.70)$ \\
\hline Rithropanopeus harrisii & 0.3 & $( \pm 0.1)^{\prime}$ & 0.13 & $( \pm 0.09)$ & 0.3 & $( \pm 0.27)$ & 0.12 & $( \pm 0.09)$ \\
\hline
\end{tabular}

trend were L. gibbosus during the spring, where both AWWBI and mean size were greater within $S$. alterniflora compared to $P$. australis, although not significantly for either ( $\mathrm{p}>0.05)$; and for $F$. majalis during the summer, where AWWBI and mean size were significantly greater $(\mathrm{p}<0.002)$ within the $S$. alterniflora than within P. australis (Figs. 5 \& 6).

\section{DISCUSSION}

Because ecosystems are not static, and natural changes occur (Kelley et al. 1995, Wray et al. 1995), it is often difficult to discern natural from anthropogenic alterations. Consequently, many perceived ecosystem changes have been attributed to human activities. On the eastern coast of the USA, a noticeable structural change associated with some marsh habitat has been the invasion and subsequent dominance of Spartina alterniflora marsh by Phragmites australis. In such cases, the general opinion is that habitat function has been diminished due to the change in macrophyte dominance. However, this evaluation may not be valid.

Numerous studies have examined the important fisheries functions of Spartina alterniflora marshes (e.g., Kneib \& Stiven 1978, Kneib 1984, Zimmerman \& Minello 1984, McIvor \& Odum 1986, Rozas et al. 1988, Hettler 1989, Minello \& Zimmerman 1992, Meyer et al. 1993, Minello et al. 1994, Rozas 1995), nekton utilization patterns (Meyer et al. 1993), and factors which may affect nekton utilization (Meyer et al. 1993, Rozas 1995). However, published information on the functions of North American Phragmites australis marshes is lacking. Information on $P$. australis marsh has generally described growth patterns (Hellings \& Gallagher 1992), its expanding areal distribution within North America (Haslam 1971, Rice 1996, Havens et al. 1997), methods of eradication and distribution control (van der Toorn \& Mook 1982, Thompson \& Shay 1985, 1989, Cowie et al. 1992), and speculation on its non-use by nekton (Hellings \& Gallager 1992, Roman et al. 1997).

The data from this study represents information on nekton use of Phragmites australis and Spartina alterniflora marshes over 3 seasons. This time frame was selected because it encompassed known peak recruitment and growth periods for dominant nekton species associated with $S$. alterniflora- and potentially $P$. australis-dominated marshes. Few significant differences in nekton species use were evident between the 2 marsh types, and neither exhibited significantly 
Table 3 (continued)

\begin{tabular}{|c|c|c|c|c|c|c|c|c|c|c|c|c|c|c|c|}
\hline \multicolumn{8}{|c|}{ July 1997} & \multicolumn{8}{|c|}{ October 1997} \\
\hline \multirow{2}{*}{\multicolumn{4}{|c|}{$\begin{array}{c}\text { P. australis } \\
\text { No. }{ }_{\text {Biomass }}\end{array}$}} & \multicolumn{4}{|c|}{ S. alterniflora } & \multicolumn{4}{|c|}{ P. australis } & \multicolumn{4}{|c|}{ S. alterniflora } \\
\hline & & Biomass & & \multicolumn{2}{|r|}{ No. } & \multicolumn{2}{|c|}{ Biomass } & \multicolumn{2}{|r|}{ No. } & \multicolumn{2}{|c|}{ Biomass } & \multicolumn{2}{|r|}{ No. } & \multicolumn{2}{|c|}{ Biomass } \\
\hline 0.0 & - & 0.0 & - & 1.2 & $( \pm 1.2)$ & 2.15 & $( \pm 2.15)$ & - & - & - & - & - & - & - & - \\
\hline 0.5 & $( \pm 0.2)$ & 21.93 & $( \pm 21.6)$ & 0.1 & $( \pm 0.1)$ & 1.78 & $( \pm 1.03)$ & - & - & - & - & - & - & - & - \\
\hline- & - & - & - & - & - & - & - & $<0.1$ & - & $<0.01$ & - & 0.0 & - & 0.00 & - \\
\hline - & - & - & - & - & - & - & - & - & - & - & - & - & - & - & - \\
\hline $15.0^{*}$ & $( \pm 6.2)$ & 3.15 & $( \pm 1.32)$ & $54.0^{*}$ & $*( \pm 10.9)$ & 10.32 & $( \pm 4.72)$ & $24.6^{*}$ & $( \pm 11.0)$ & 14.03 & $( \pm 7.74)$ & $62.8^{*}$ & $*( \pm 9.8)$ & 25.03 & $( \pm 3.54)$ \\
\hline 0.2 & $( \pm 0.1)$ & 0.73 & $( \pm 0.45)$ & 0.4 & $( \pm 0.3)$ & 1.22 & $( \pm 1.11)$ & 20.0 & $( \pm 8.2)$ & 13.88 & $( \pm 5.89)$ & 51.8 & - & 45.35 & $( \pm 26.45)$ \\
\hline 253.2 & $( \pm 71.8)$ & 231.70 & $( \pm 79.34)$ & 282.3 & $( \pm 09.5)$ & 199.40 & $( \pm 83.93)$ & 90.1 & $( \pm 62.0)$ & 106.85 & $( \pm 76.66)$ & 108.0 & $( \pm 18.1)$ & 101.90 & $( \pm 21.42)$ \\
\hline 9.3 & $( \pm 9.0)$ & 3.70 & $( \pm 3.59)$ & 1.4 & $( \pm 0.8)$ & 0.55 & $( \pm 0.34)$ & $<0.1$ & - & 0.02 & $( \pm 0.01)$ & $<0.1$ & - & $<0.01$ & - \\
\hline 2.5 & $( \pm 2.3)$ & 0.68 & $( \pm 0.60)$ & 0.8 & $( \pm 0.3)$ & 1.88 & $( \pm 0.64)$ & 1.4 & $( \pm 1.1)$ & 8.73 & $( \pm 6.24)$ & 3.0 & $( \pm 0.9)$ & 10.26 & $( \pm 4.00)$ \\
\hline 1.2 & $( \pm 0.7)$ & 0.13 & $( \pm 0.09)$ & 2.0 & $( \pm 1.4)$ & 0.26 & $( \pm 0.16)$ & $<0.1$ & - & $<0.01$ & - & 0.4 & $( \pm 0.2)$ & 0.05 & $( \pm 0.02)$ \\
\hline- & - & - & - & - & - & - & & - & $<0.1-$ & 0.03 & $( \pm 0.02)$ & $<0.1$ & - & 0.02 & $( \pm 0.02)$ \\
\hline$<0.1$ & - & 0.35 & $( \pm 0.35)$ & 0.0 & - & 0.00 & - & - & - & - & - & - & - & - & - \\
\hline 1.6 & $( \pm 0.8)$ & 22.20 & $( \pm 12.78)$ & 2.5 & $( \pm 2.3)$ & 26.96 & $( \pm 24.00)$ & $0.4^{*}$ & $( \pm 0.1)$ & $3.49^{*}$ & $( \pm 1.01)$ & $0.1^{*}$ & $*( \pm 0.1)$ & $0.25^{*}$ & * $( \pm 0.17)$ \\
\hline- & - & - & - & - & - & - & - & $<0.1$ & - & 0.02 & $( \pm 0.01)$ & $<0.1$ & - & 0.02 & $( \pm 0.01)$ \\
\hline 0.3 & $( \pm 0.2)$ & 0.02 & $( \pm 0.02)$ & 1.2 & $( \pm 0.6)$ & 0.08 & $( \pm 0.04)$ & 14.1 & $( \pm 7.3)$ & 2.25 & $( \pm 1.14)$ & 23.0 & $( \pm 17.5)$ & 4.42 & $( \pm 3.15)$ \\
\hline 8.9 & $( \pm 3.3)$ & 1.93 & $( \pm 0.66)$ & 19.0 & $( \pm 13.4)$ & 4.66 & $( \pm 2.60)$ & 6.6 & $( \pm 2.4)$ & 2.26 & $( \pm 0.95)$ & 27.2 & $( \pm 15.4)$ & 9.62 & $( \pm 5.23)$ \\
\hline 0.3 & $( \pm 0.1)$ & 0.20 & $( \pm 0.07)$ & 4.3 & $( \pm 1.8)$ & 2.56 & $( \pm 1.04)$ & $<0.1$ & - & 0.04 & $( \pm 0.02)$ & 2.0 & $( \pm 1.7)$ & 2.78 & $( \pm 2.39)$ \\
\hline 3.4 & $( \pm 0.4)$ & 56.29 & $( \pm 15.50)$ & 3.4 & $( \pm 1.2)$ & 70.41 & $( \pm 40.73)$ & 0.3 & $( \pm 0.2)$ & 7.41 & $( \pm 0.45)$ & 0.2 & $( \pm 0.1)$ & 4.38 & $( \pm 2.65)$ \\
\hline$<0.1$ & - & 0.89 & $( \pm 0.89)$ & 0.0 & - & 0.00 & - & - & - & - & - & - & - & - & - \\
\hline$<0.1$ & - & 1.70 & $( \pm 1.70)$ & $<0.1$ & - & 3.35 & $( \pm 0.84)$ & - & - & - & - & - & - & - & - \\
\hline$<0.1$ & - & 0.01 & $( \pm 0.01)$ & 0.0 & - & 0.00 & - & - & - & - & - & - & - & - & - \\
\hline 0.1 & $(+0.1)$ & 4.83 & $( \pm 390)$ & 0.0 & - & 0.00 & - & - & - & - & - & - & - & - & - \\
\hline- & - & - & - & - & - & - & - & 0.0 & - & 0.00 & - & $<0.1$ & _- & $<0.01$ & _- \\
\hline 2.4 & $(+0.18)$ & 0.14 & $( \pm 0.10)$ & 1.0 & $( \pm 0.7)$ & 0.06 & $( \pm 0.04)$ & 671.0 & $( \pm 347.6)$ & 76.91 & $( \pm 42.19)$ & 235.0 & $( \pm 12.2)$ & 27.13 & $( \pm 12.22)$ \\
\hline 0.4 & $(+0.3)$ & 0.12 & $( \pm 0.09)$ & 0.2 & $( \pm 0.2)$ & 0.10 & $( \pm 0.09)$ & 0.9 & $( \pm 0.3)$ & 0.22 & $( \pm 0.09)$ & 0.7 & $( \pm 0.7)$ & 0.32 & $( \pm 0.17)$ \\
\hline
\end{tabular}

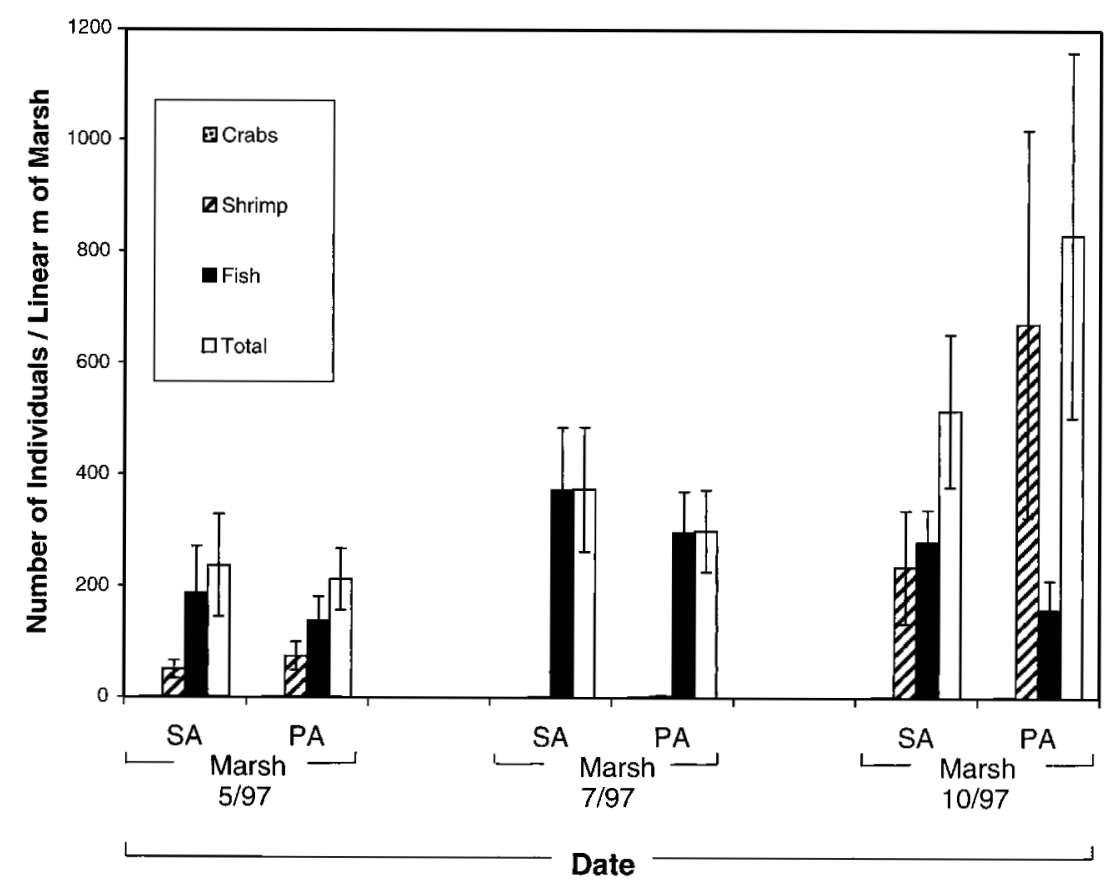

Fig. 3. Mean abundance per linear meter of marsh fringe ( $\pm 1 \mathrm{SE})$ by date, for fish, shrimp and crab taxonomic groups, and totals for all combined, within Spartina alterniflora (SA), and Phragmites australis (PA) marsh types. $\mathrm{n}=5$ for the means of both $S$. alterniflora and $P$. australis marsh types 


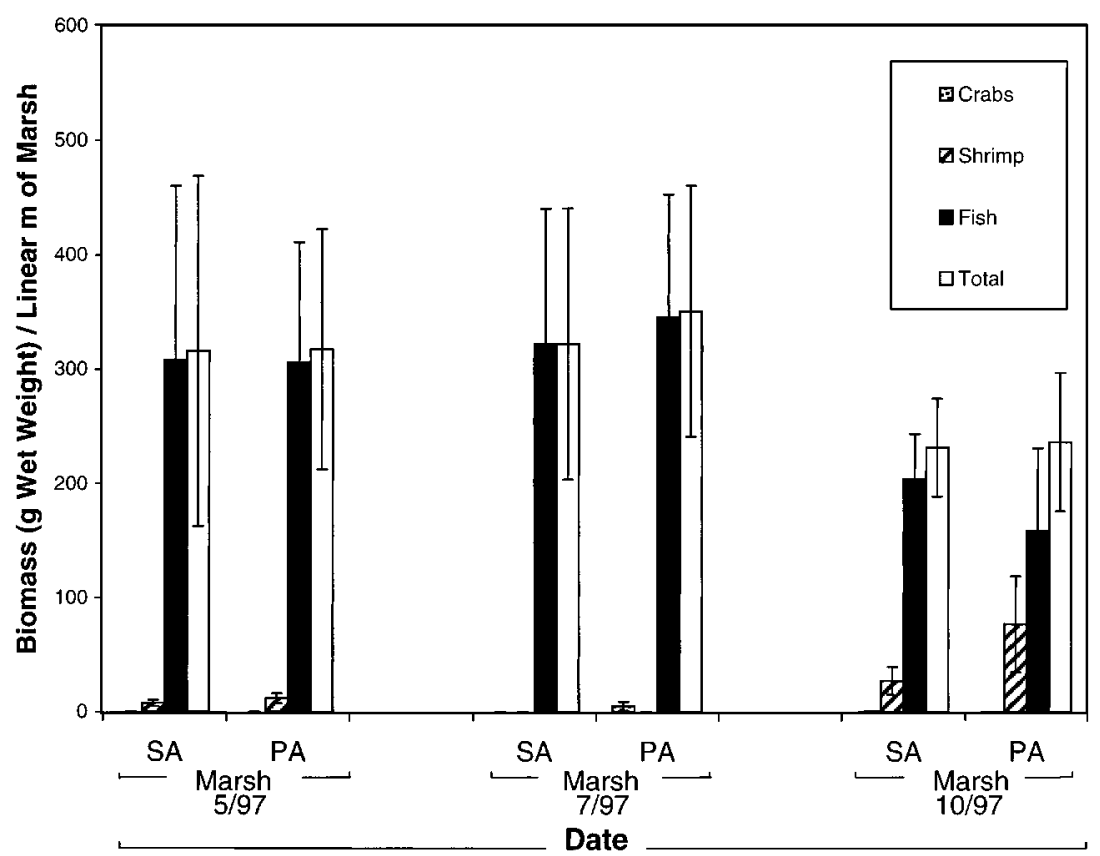

Fig. 4. Mean wet weight biomass, per linear meter of marsh fringe $( \pm 1 \mathrm{SE})$ by date, for fish, shrimp and crab taxonomic groups, and totals for all combined, within Spartina alterniflora (SA), and Phragmites australis (PA) marsh types. $\mathrm{n}=5$ for the means of both $S$. alterniflora and $P$. australis marsh types

higher nekton species diversity (number of species), total nekton abundance or biomass than the other. However, trends which might be indicative of potentially divergent utilization patterns by nekton were observed. For example, killifish (Fundulus heterocli- tus, F. diaphanus, F. majalis and Cyprinodon variegatus), were typically more abundant in $S$. alterniflorathan in $P$. australis-dominated marshes. In contrast, shrimp (Palaemonetes pugio) abundances were reciprocal. We suspect this differential use pattern might be

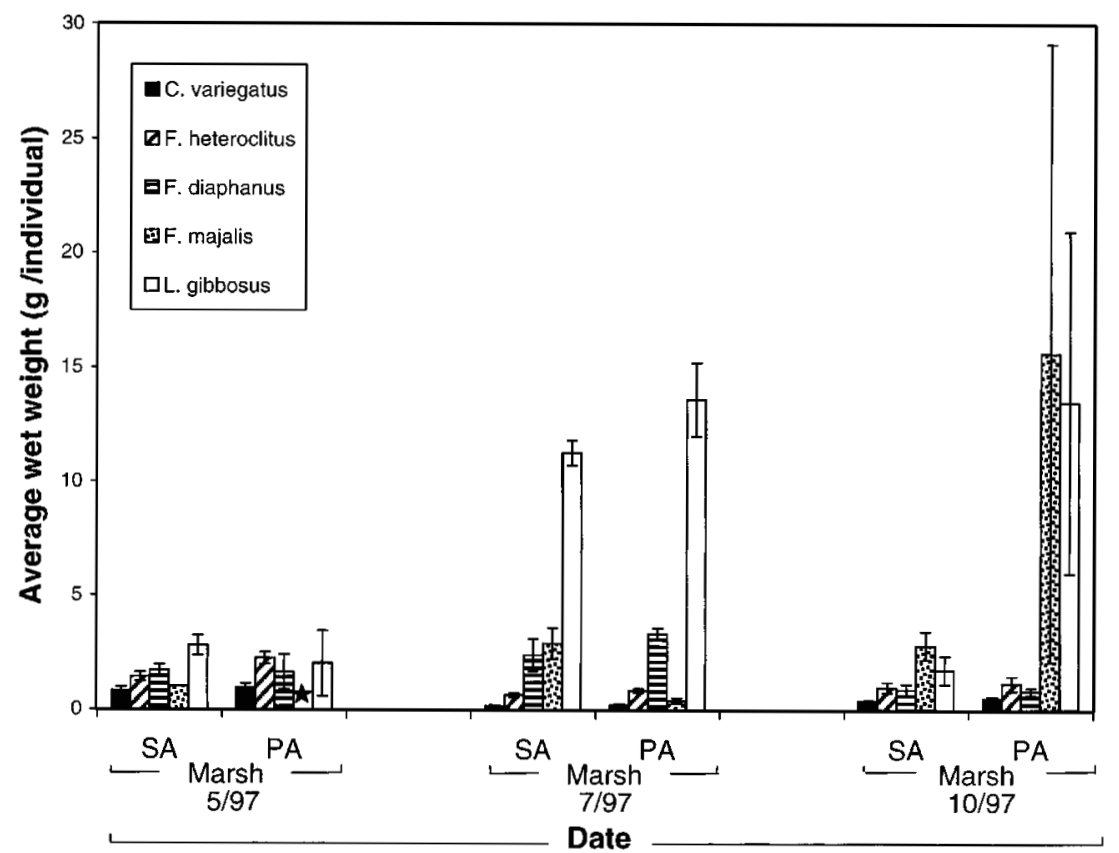

Fig. 5. Average wet weight biomass per individual $( \pm 1 \mathrm{SE})$ by date, for the dominant fish species within Spartina alterniflora (SA), and Phragmites australis (PA) marsh types. $(\star)$ No individuals of that species were collected within that marsh type at that collection date. Full specific names in Table 2 


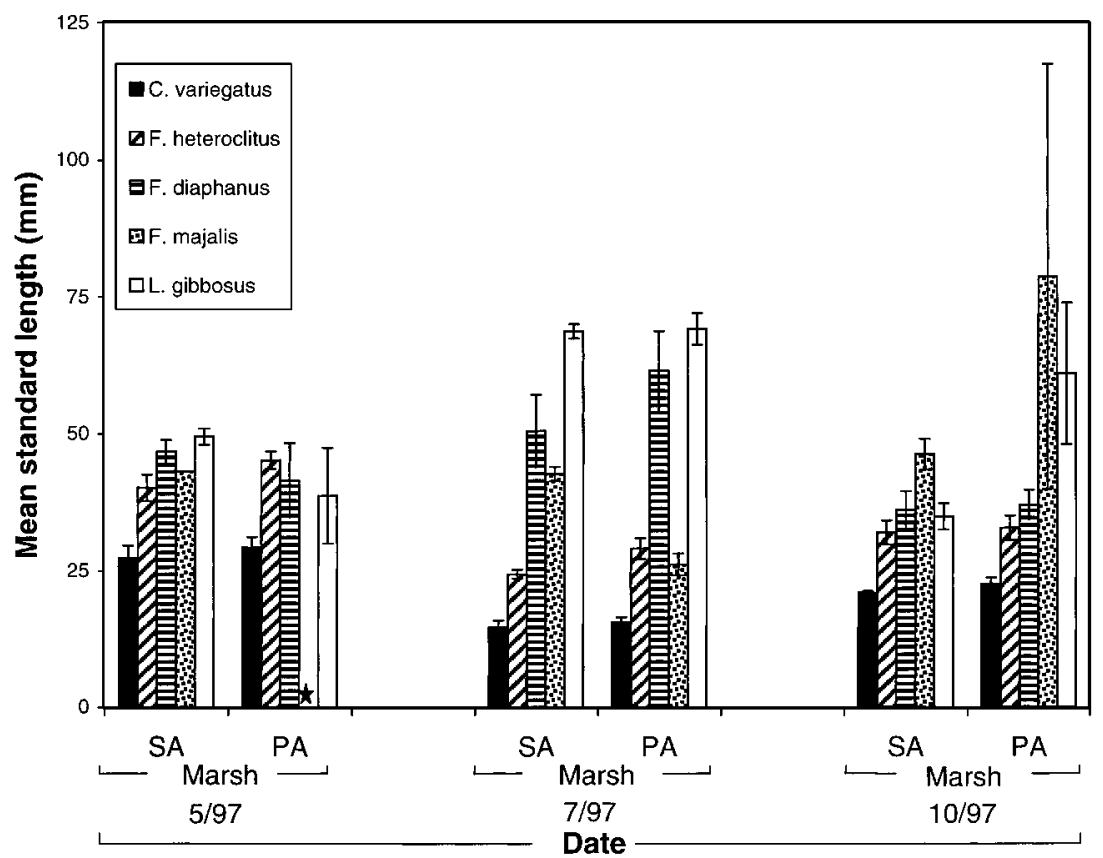

Fig. 6. Mean standard length per individual $( \pm 1 \mathrm{SE})$ by date, for the dominant fish species within Spartina alterniflora (SA), and Phragmites australis (PA) marsh types. $(\star)$ No individuals of that species were collected within that marsh type at that collection date. Full specific names in Table 2

best explained by predator/prey interactions including prey-habitat shifts due to predator occurrence, as noted for Lepomis macrochirus when in the presence of Micropterus salmoides (Wenner et al. 1983) and P. pugio when in the presence of $F$. heteroclitus (Posey \& Hines 1991). Posey \& Hines (1991) further noted that within aquaria $P$. pugio does shift from deeper-water habitat to shallow-water habitat in the presence of a predator, in particular $F$. heteroclitus. This interactionbased model probably best explains the trend of higher abundances of $P$. pugio in the P. australis compared to $S$. alterniflora marshes because of the slightly shallower water closer to the marsh edge in the P. australis than the $S$. alterniflora marshes sampled. The potential of predator/prey interactions is further supported by fish size-distribution trends within the $P$. australis and $S$. alterniflora marshes, particularly during the fall (peak $P$. pugio abundance), when more known predators of Palaemonetes spp., larger-sized Fundulus spp. (Kneib 1988, Cross \& Stiven 1999), and Lepomis spp. (Rottmann \& Anderson 1976) were observed within $P$. australis than within $S$. alterniflora marshes.

While potential differences in nekton utilization patterns might occur between Phragmites australis and Spartina alterniflora marshes there were substantial similarities among these marsh types. Both marsh types supported diverse nekton populations, with the nekton species comprising $95 \%$ of the abundance and biomass typical of 'highly productive' S. alterniflora marshes within the southeastern USA (Hettler 1989) and Chesapeake Bay (McIvor \& Odum 1986, Rozas \& Odum 1987, Rozas et al. 1988). It was also evident that both the $P$. australis- and $S$. alterniflora-dominated marsh habitats we sampled were highly productive and supported an order of magnitude higher nekton abundance than observed for $S$. alterniflora marshes in the southeastern USA sampled with similar gear during the same months by Hettler (1989).

Although vegetation structure is important for nekton (Heck \& Thoman 1981), other physical parameters have substantial effects on nekton habitat-use (Rozas 1995) and might strongly influence fisheries use. The collection of substantial densities of numerous estuarine salt-marsh species by Rozas \& Hackney (1984) in intertidal oligohaline bulrush (Scirpus spp.) and cattail (Typha spp.) marshes also indicates that physical conditions of wetlands (elevation, salinity, slope etc.) might be more important than the occurrence of a particular macrophyte species. Noted similarities in diet and feeding potential for Fundulus heteroclitus between high marsh habitat with and without Phragmites australis (Fell et al. 1998) further supports this assertion. Hence, a shift in marsh vegetation dominance in a particular area may not indicate that habitat value for nekton has significantly changed.

Ecosystem disturbance has occurred throughout the world due to natural (Kelley et al. 1995) and anthro- 
pogenic processes at scales ranging from entire river systems in Asia (Dudgeon 1992) and North America (Serafy et al. 1994), to coastal oceans of Europe (Rico \& Fernandez 1997), to small individual marshes and creeks within the Chesapeake Bay of North America (Rice 1996). These disruptions have typically been considered detrimental to ecological processes important for ecosystem function. Cases supporting this assertion include the effects on the Asian river systems noted by Dudgeon (1992), and introduction of the macrophyte Myriophyllum spicatum into North America, which encroaches upon aquatic Potamogeton spp.-Vallisneria spp. communities, making the habitat less supportive of nekton (Keast 1984). However, perceived change in an ecosystem or locale may not necessarily have disastrous effects. Alterations might be more cosmetic in nature than disruptive, with the basic functions that drive the system still in good order. For example, habitats with different dominant macrophytes or undergoing a change in macrophyte dominance may not equate with change or difference in habitat function as observed by Fonseca et al. (1996) for nekton use of different seagrass species in the southeastern USA and by Fell et al. (1998) for highmarsh macrophytes in the northeastern USA. Similarly, the presence of the invasive macrophyte Hydrilla verticillata in the waterways of temperate North America has been noted to provide a high-quality habitat for nekton species (Killgore et al. 1989, Serafy et al. 1994) as has Eurasian water-milfoil (Borawa et al. 1979).

The contention that within North America only Spartina spp. marshes can provide quality salt-marsh habitat for nekton needs to be reevaluated. Current efforts to eliminate Phragmites australis from regularly flooded salt marshes to establish $S$. alterniflora plantings may not increase nekton use. $P$. australis invasion and spread to areas through anthropogenic changes in physical or environmental factors (Roman et al. 1984, Havens et al. 1997) may be inevitable, and efforts to control the $P$. australis spread may consume resources and not influence vegetation change. Perhaps, instead of altering existing marshes in an attempt to provide the functions valued, resources might be better used to conserve, restore or create salt marsh.

Because environmental managers and regulators must consider benefits of habitat use by a wide range of users, including nekton, avian and mammalian, the ultimate goal of a wetland's function needs to be considered to best use resources to attain well defined objectives. To attain these functional objectives, it is essential that reliable information on the functional value of wetland habitats be available. It is evident that information on faunal use of many habitat types is limited and often generalized. Additionally, the physical factors that influence the utilization, production and functions of habitats including salt marshes are poorly understood. It is easier to assign higher value to a habitat that is better understood than to a habitat which is not. As a result, when decisions are made on how to best manage habitat resources to provide high yields, habitats with known functional attributes are often chosen over habitats for which functional attributes are unknown. The information gaps on the functions of all habitat types, including salt marshes, need to be filled if good environmental management decisions are to be made.

Acknowledgements. The authors wish to thank Chris Doley, Raymond Li, Laura Hamilton, Bob Murphy and Derek Orner for assistance in the field, rain or shine. We also thank Glen Montgomery for sorting and identifying all those thousands of fishes and shrimps and Fred (Fritz) Rohde for validating fish identification. Gordon Thayer, William Hettler Jr, Allyn Powell, Alan Stoner and 3 anonymous reviewers provided valuable comments that substantially improved this manuscript. This project was funded by NOAA's National Marine Fisheries Service Restoration Center. This manuscript is dedicated to the memory of Eunice R. Meyer (1919-1999), the senior author's first mentor.

\section{LITERATURE CITED}

Armitage PD, Pardo I, Brown A (1995) Temporal constancy of faunal assemblages in 'mesohabitats' - application to management? Arch Hydrobiol 133:367-387

Arnold SA, Ormerod SJ (1997) Aquatic macroinvertebrates and environmental gradients in Phragmites reedswamps: implications for conservation. Aquat Conserv: Mar Freshw Ecosyst 7:153-163

Balint MA, Hansson W, Hansson L (1998) Food competition and niche separation between fish and the red-necked grebe Podiceps grisegena (Boddaert, 1873). Hydrobiologia 368:75-81

Baltz DM, Rakocinski C, Fleeger JW (1993) Microhabitat use by marsh-edge fishes in a Louisiana estuary. Environ Biol Fish 36:109-126

Benoit LK, Askins RA (1999) Impact of the spread of Phragmites on the distribution of birds in Connecticut tidal marshes. Wetlands 19:194-208

Blaber SJM (1982) The ecology of Sphyraena barracuda (Osteichthyes: Perciformes) in the Kosi system with notes on the Sphyraenidae of other Natal estuaries. S Afr J Sci $17: 171-176$

Boesch DF, Turner RE (1984) Dependence of fishery species on salt marshes: the role of food and refuge. Estuaries 7 : $460-468$

Borawa JC, Kerby JH, Huish MT, Mullis AW (1979) Currituck Sound fish populations before and after infestation by Eurasian water-milfoil. Proc Annu Conf SEast Assoc Fish Wildl Ag 32:520-528

Bozeman EL Jr, Dean JM (1980) The abundance of estuarine larval and juvenile fish in a South Carolina creek. Estuaries 3:89-97

Broyer J, Varagnat P (1998) Habitat du heron pourpre Ardea purpurea sur les etangs de pisciculture en France. Alauda 66:221-228

Caffrey JM (1996) Glyphosate in fisheries management. Hydrobiologia 340:259-263 
Cowie NR, Sutherland WJ, Ditlhogo MKM, James R (1992) The effects of conservation management of reed beds. II. The flora and litter disappearance. J Appl Ecol 29: 277-284

Cross RE, Stiven AE (1999) Size-dependent interactions in salt marsh fish (Fundulus heteroclitus Linnaeus) and shrimp (Palaemonetes pugio Holthuis). J Exp Mar Biol Ecol 242:179-199

Doergeloh W (1985) Food selection and competition for food among three species, Salmo gairdneri, Barbus aeneus and Clarias gariepinus (Abstract). S Afr J Sci 81:693

Dudgeon D (1992) Endangered ecosystems: a review of the conservation status of tropical Asian rivers. Hydrobiologia 248:167-191

Fell P, Weissbach SP, Jones DA, Fallon MA, Zeppieri JA, Faison EK, Lennon KA, Newberry KJ, Reddington LK (1998) Does invasion of oligohaline tidal marshes by reed grass, Phragmites australis, affect the availability of prey resources for the mummichog, Fundulus heteroclitus? J Exp Mar Biol Ecol 222:59-77

Fonseca MS, Meyer DL, Hall MO (1996) Development of planted seagrass beds in Tampa Bay, Florida, USA. II. Faunal components. Mar Ecol Prog Ser 132:141-156

Haslam SM (1971) The development and establishment of young plants of Phragmites communis Trin. Ann Bot 35:1059-1072

Havens KJ, Priest WI III, Berquist H (1997) Investigation and long-term monitoring of Phragmites australis within Virginia's constructed wetland sites. Environ Manag 21: $599-605$

Heck KL, Thoman TA (1981) Experiments on predator-prey interactions in vegetated aquatic habitats. J Exp Mar Biol Ecol 53:125-134

Hellings SE, Gallagher JL (1992) The effects of salinity and flooding on Phragmites australis. J Appl Ecol 29:41-49

Herke WH (1971) Use of natural and semi-impounded, Louisiana tidal marshes as nurseries for fishes and crustaceans. PhD thesis, Louisiana State University, Baton Rouge

Hettler WF Jr (1989) Nekton use of regularly-flooded saltmarsh cordgrass habitat in North Carolina, USA. Mar Ecol Prog Ser 56:111-118

Kay SH (1995) Efficacy of wipe-on applications of glyphosate and imazapyr on common reed in aquatic sites. J Aquat Plant Manag 33:25-26

Keast A (1984) The introduced aquatic macrophyte, Myriophyllum spicatum, as habitat for fish and their invertebrate prey. Can J Zool 62:1289-1303

Kelley JT, Gehrels WR, Belknap DF (1995) Late holocene relative sea-level rise and the geological development of tidal marshes at Wells, Maine, USA. J Coast Res 11: 136-153

Killgore KJ, Morgan RP II, Rybicki NB (1989) Distribution and abundance of fishes associated with submersed aquatic plants in the Potomac River. N Am J Fish Manag 9: 101-111

Kneib RT (1984) Patterns of utilization of intertidal salt marsh by larvae and juveniles of Fundulus heteroclitus (linnaeus) and Fundulus luciae (Baird). J Exp Mar Biol Ecol 83:41-51

Kneib RT (1988) Testing the indirect effects of predation in an intertidal soft-bottom community. Ecology 69: 1795-1805

Kneib RT, Stiven AE (1978) Growth, reproduction, and feeding of Fundulus heteroclitus (L) in a North Carolina salt marsh. J Exp Mar Biol Ecol 31:121-140

McIvor CC, Odum WE (1986) The flume net: a quantitative method for sampling fishes and macrocrustaceans on tidal marsh surfaces. Estuaries 9:219-224

Meyer DL (1994) Habitat partitioning between the xanthid crabs Panopeus herbstii and Eurypanopeus depressus on intertidal oyster reefs (Crassostrea virginica) in southeastern North Carolina. Estuaries 17:674-679

Meyer DL, Fonseca MS, Thayer VG, Kenworthy WJ, Colby DR (1993) Faunal use of restored marsh and seagrass habitat. In: Magoon OT, Converse H, Miner D, Tobin LT, Clark D (eds) Coastal Zone '93, Vol 4. Proceedings of the Eighth Symposium on Coastal Ocean Management, July 18-22 New Orleans, Louisiana. American Society of Civil Engineers, New York, p 858-1863

Meyer DL, Townsend EC, Thayer GW (1997) Stabilization and erosional control value of oyster cultch for intertidal marsh. Restor Ecol 5:93-99

Minello TJ, Zimmerman RJ (1992) Utilization of natural and transplanted Texas salt marshes by fish and decapod crustaceans. Mar Ecol Prog Ser 90:273-285

Minello TJ, Zimmerman RJ, Medina R (1994) The importance of edge for natant macrofauna in a created salt marsh. Wetlands 14:184-198

Newell B (1978) The Gippsland regional environmental study (Abstract). Aust Mar Sci Bull 62

Niering WA, Warren RS (1977) Our dynamic tidal marshes: vegetation changes as revealed by peat analysis. Bull Conn Arbor 12:1-22

Orson RA, Warren RS, Niering WA (1987) Development of a tidal marsh in a New England river valley. Estuaries 10: $20-27$

Ostendorp W (1993) Reed bed characteristics and significance of reeds in landscape ecology. In: Ostendorp W, Krumscheid-Plankert P (eds) Lakeshore deterioration and restoration works in Central Europe. G Fischer Verlag, Stuttgart, p 149-161

Ott L (1993) An introduction to statistical methods and data analysis. Duxbury Press, Belmont, CA

Peterson GW, Turner RE (1994) The value of salt marsh edge vs interior as a habitat for fish and decapod crustaceans in a Louisiana tidal marsh. Estuaries 17:235-262

Posey MH, Hines AH (1991) Complex predator-prey interactions within an estuarine benthic community. Ecology 72:2155-2169

Rice DM (1996) Determining the distribution and expansion rate of Phragmites australis in six Chesapeake Bay area marshes. MS thesis, University of Maryland, College Park

Rico JM, Fernandez C (1997) Ecology of Sargassum muticum on the North Coast of Spain. II. Physiological differences between Sargassum muticum and Cystoseira nodicaulis. Bot Mar 40:405-410

Roman CT, Niering WA, Warren RS (1984) Salt marsh vegetation change in response to tidal restriction. Environ Manag 8:141-150

Roman CT, LaBash CL, Raposa K, MacPhee G (1997) Restoration of the Sachuest Point salt marsh (Middletown, RI): pre-restoration ecology baseline information. NOAA/ National Marine Fisheries Service, Gloucester, MA

Rottmann RW, Anderson RO (1976) Limnological and ecological effects of grass carp in ponds. Proc Annu Conf Southeast Assoc Game Fish Comm 30:24-39

Rozas LP (1995) Hydroperiod and its influence on nekton use of the salt marsh: a pulsing ecosystem. Estuaries 18: 579-590

Rozas LP, Hackney CT (1984) Use of oligohaline marshes by fishes and macrofaunal crustaceans in North Carolina. Estuaries 7:213-224 
Rozas LP, Odum WE (1987) Use of tidal freshwater marshes by fishes and macrofaunal crustaceans along a marsh stream-order gradient. Estuaries 10:36-43

Rozas LP, McIvor CC, Odum WE (1988) Intertidal rivulets and creekbanks: corridors between tidal creeks and marshes. Mar Ecol Prog Ser 47:303-307

SAS Institute Inc (1985) Guide for Personal Computers, Version 6 Edition. SAS Institute Inc, Cary, NC

Serafy JE, Harrell RM, Hurley LM (1994) Mechanical removal of Hydrilla in Potomac River, Maryland: local impacts on vegetation and associated fishes. J Freshw Ecol 9: 135-143

Sinicrope TL, Hine PG, Warren RS, Niering WA (1990) Restoration of an impounded salt marsh in New England. Estuaries 13:25-30

Thompson DJ, Shay JM (1985) The effects of fire on Phragmites australis in the Delta Marsh, Manitoba. Can J Bot 63:1864-1869

Thompson DJ, Shay JM (1989) First-year response of a Phragmites marsh community to seasonal burning. Can J Bot 67:1448-1455

Tscharntke T (1992) Fragmentation of Phragmites habitats, minimum viable population size, habitat suitability, and local extinction of moths, midges, flies, aphids, and birds. Conserv Biol 6:530-536

van der Toorn J, Mook JH (1982) The influence of environ-

Editorial responsibility: Otto Kinne (Editor),

Oldendorf/Luhe, Germany mental factors and management on stands of Phragmites australis. I. Effects of burning, frost and insect damage on shoot density and shoot size. J Appl Ecol 19:477-499

Wainright SC, Weinstein MP, Able KW, Currin CA (2000) Relative importance of benthic microalgae, phytoplankton and detritus of smooth cordgrass (Spartina) and the common reed (Phragmites) to brackish marsh food webs. Mar Ecol Prog Ser 200:77-91

Webb EC, Mendelssohn IA, Wilsey BJ (1995) Causes for vegetation die back in a Louisiana salt marsh: a bioassay approach. Aquat Bot 51:281-289

Wenner EE, Gilliam JF, Hall DJ, Mittelbach GG (1983) An experimental test of the effects of predation risk on habitat use in fish. Ecology 64:1540-1548

Whitfield AK (1980) A quantitative study of the trophic relationships within the fish community of the Mhlanga Estuary, South Africa. Estuar Coast Mar Sci 10:417-435

Wray RD, Leatherman SP, Nicholls RJ (1995) Historic and future land loss for upland and marsh islands in the Chesapeake Bay, Maryland, USA. J Coast Res 11: 1195-1203

Yu D, Yu H, Song L, Li D, Chai F (1994) Study on the structure and function of aquatic plant community of Hongqi Lake in Daqing oil-field. Hydrobiol Sin 18:50-58

Zimmerman RJ, Minello TJ (1984) Densities of Penaeus aztecus, Penaeus setiferus and other natant macrofauna in a Texas salt marsh. Estuaries 7:421-433

Submitted: July 6, 1999; Accepted: June 27, 2000

Proofs received from author(s): December 14, 2000 